\title{
Mineralogical identification new bodies in Zimnyi Bereg area: generalization and application for searching of the new diamond deposits in Archangelsk province
}

\author{
V. K. Garanin ${ }^{1}$, K.V. Garanin ${ }^{1}$, A.P. Gunin ${ }^{2}$, V.L. Larchenko ${ }^{2}$ and G.V. Minchenko ${ }^{2}$ \\ ${ }^{I}$ M.V. Lomonosov Moscow State University, Moscow, Russia \\ ${ }^{2}$ ALROSA-Pomorie, Archangelsk, Russia
}

During 2005-2007 new kimberlites were discovered in Kepinskoe field (Zimnyi Bereg, Archangelsk province, NW Russia) by geologists of the "ALROSA-Pomorie" company: Galina, An-746b, Rozhdestvenskaya pipes and An-495v sill. Kimberlites are presented by Fe-Ti series and located within the limits of the Tovsky ridge and Padunsky graben on the Zimneberezhny basement uplift (Bogatikov et. al, 1999). Bodies are characterized by low magnetic anomalies with intensity 10-14 $\mathrm{nTl}$. Exploration was done by drill-holes with 100-250 m depths. Different body-structures were identified. Xeno-tuff-breccias presented in upper crater parts than it is going to breccias with a depth. Picroilmenite is dominated among diamond indicator minerals (DIM), spinels and garnets are also presented, chrome-diopside is absent. High DIM content is determined for Galina and An-746b pipes, low concentrations are typical for Rozhdestvenskaya, An-495a pipes and related with last one sill 495v.

Features of the DIM composition and their paragenesis were observed. Results of DIM electron-probe analyses were formed to database and statistically treated with an application of the chemical-genetic classifications (Larchenko et al., 2004).

\section{Garnet}

Individuals from dunite-harzburgites and peridotites, lherzolites, ilmenite hyperbasites, websterites are prevailing (total 93\%) in Galina pipe. Eclogitic garnets are presented by garnets from diamondiferous ilmeniterutile $\mathrm{Mg}-\mathrm{Fe}(6 \%)$ and $\mathrm{Mg}(1 \%)$ eclogites. Diamond paragenesis garnets are presented mainly by ultra-basic $(12 \%)$ and rarely eclogitic paragenesis.

Garnets from $746 \mathrm{~b}$ pipe present only ultra-basic paragenesis rocks: lherzolites (68\%), ilmenitehyperbasites (4\%) and websterites (22\%). Duniteharzburgites is a source of the diamond paragenesis garnets $(6 \%)$.

Garnets from high-diamondiferous dunites and harzburgites were not discovered in
Rozhdestvenskaya pipe. There are garnets from lherzolites with low Cr-content. Only one garnet from alkremites was identified. Singular garnets from eclogites were detected.

Generally there are no garnets from wehrlites, alkremites, Al- and Ca-eclogites - it is characteristic of ADP kimberlites.

Garnets from $495 \mathrm{v}$ sill are presented by uncommon grains from lherzolites. The others ultra-basic or eclogitic paragenesis are not identified.

\section{Cr-spinel}

Low content of the Cr-spinel from highdiamondiferous dunites and harzburgites ( $>60.0 \mathrm{wt} . \%$ $\mathrm{Cr}_{2} \mathrm{O}_{3}$ and $<1.0$ wt.\% $\mathrm{TiO}_{2}$ ) is presented in all objects, except Rozhdestvenskaya.

Large number Cr-spinels from cataclased lherzolites, garnet-clinopyroxene-spinel growths and zonal garnets with $\mathrm{Cr}$-spinel inclusions is determined. This Cr-spinel paragenesis is widely presented in ADP bodies with low diamond grade and it evidences extremely mantle metasomatosis grade, it leads to structure transformation of the lherzolites after fluids influence and digression of the diamond grade (Garanin, 2006). It evidences aggressive environment for diamond. Morphological features of the recovered diamonds distinctly show traces of the strong solution and corrosion.

\section{Picroilmenite}

There is no picroilmenite in Rozhdestvenskaya pipe. Picroilmenite from other bodies has lower $\mathrm{Cr}_{2} \mathrm{O}_{3}$ content $(<2$ wt.\%) compare to V. Grib pipe picroilmenite ( $<8 \mathrm{wt} . \%)$. It is negative characteristic for industrial diamond grade of the Fe-Ti-kimberlites. All of analyzed picroilmenites (Cr-contented) are from ilmenite hyperbazites. 
We suggested the next types of the Fe-Ti-series alkaline-ultrabasic magmatites can be discovered in Kepinskoe field: (1) singular industrial diamond deposit; (2) several low diamondiferous bodies; (3) abundantly poor-diamondiferous bodies.

\section{References}

Bogatikov O.A., Garanin V.K., Kononova V.A. et al. Arkhangelsk diamondiferous province (geology, petrography, geochemistry and mineralogy). Moscow, ed. MSU, 1999, 522 p.

Garanin V.K. Mineralogy of the kimberlites and related rocks from Russian diamond provinces relative to their genesis and searching. Moscow, ed. MSU, 2006, 48 p.

Larchenko V.A., Stepanov V.P., Minchenko G.V., Kechik I.A. Diamond grade of the kimberlites and related rocks from Zimny Bereg. // Vestnik VSU. Geology, 2004. Pp. 134-146. 